PERIODICALS OF ENGINEERING AND NATURAL SCIENCES

Vol. 5 No. 1 (2017) - Special Issue (Recent Topics in Environmental Science)

Available online at: http://pen.ius.edu.ba

\title{
A comparative study on Soil Properties and Applications Review with EERA and NERA in İstanbul-MARMARAY Project between Kazlıçeşme to Sirkeci
}

\author{
Günay Beyhan \\ Sakarya University, Engineering Faculty -Sakarya \\ Turkey \\ gbeyhan@sakarya.edu.tr
}

\author{
Ayhan Keskinsezer \\ Sakarya University, Engineering Faculty-Sakarya \\ Turkey
}

\author{
Sunay Beyhan \\ DumlupınarUniversity, Engineering Faculty-Kütahya \\ Turkey
}

\begin{abstract}
Over the course of history Marmara region in North-western Turkey has been the site of numerous destructive earthquakes. Based on historical and instrumental earthquake records, the Marmara sea region is one of the most seismically active regions of the Eastern Mediterranean. The Marmara region is under the influence of the western part of the North Anatolian Fault Zone (NAFZ) and the N-S extensional regime of Western Turkey. Therefore, the earthquake risk analysis is very important for the MARMARAY Project. $76 \mathrm{~km}$-long MARMARAY Project is an important project not only for Turkey but also for the world because it joins the two continents through railway. It will also serve for a comfortable and healthy way of environment, providing a contemporary solution for urban transportation.
\end{abstract}

Geotechnical and geological parameters of the region were obtained from analyses of seven boreholes. In this paper, using average wave velocities in layers, thickness, density and formation data based on the PS logs, $43 \mathrm{~m}$ and $65.5 \mathrm{~m}$ depths ranging from 7 different boring $\operatorname{logs}$ in a ground-wise different geological regions in Istanbul, ground response functions were obtained. Based on the soil profiles transferred to EERA (Equivalent - Linear Earthquake Site Response Analyses of Layered Soil Deposits) and NERA (Nonlinear Earthquake Site Response Analyses of Layered Soil Deposits) softwares, the rock soil record of August 17, 1999 Kocaeli earthquake in Istanbul - Beşiktaş Ministry of Public Works and Settlement (IBMPWS), response and design spectrums that may be considered crucial in case of an earthquake were obtained. The acceleration record was used as an input motion having PGA value of 0,04287 g (east-west component) which was applied on sublayers (i.e. sand, gravel, clay) using EERA and NERA programs. The analysis is done by keeping constant damping ratio of 5\%.

Also nonlinear analysis was compared with the linear method of analysis. Stages involved in ground response analyses to develop site-specific response spectra at a soil site are summarized. Some of the known site response analysis methods are summarized and similarities and differences between linear and nonlinear methods.

Keywords: PS logging; MARMARAY; EERA; NERA; Earthquake Site Response Analysis; Seismic Excitation

\section{Introduction}

Because a major earthquake is expected in the off-shore south of İstanbul along the North Anatolian Fault Zone in the upcoming decades, the Bosporus and its vicinity with historical monuments and big engineering structures including suspended bridges and high-rise buildings either completed or under construction have a very high probability to expose destructive strongground motion. One of the big and complicated engineering structure in the Bosporus is the newlycompleted MARMARAY including an immersed tunnel structure over the bottom with many public stations and tens of kilometers of railway connections onshore.
Site response analysis is usually the first step of any seismic soil-structure study. Geotechnical earthquake engineers and engineering geologist have been trying to find both practical and most appropriate solution techniques for ground response analysis under earthquake loadings. Site response of a two layered soil deposit with the assumption of linear and rigid base bedrock (or viscoelastic half-space) was analyzed by using linear approach. The amplification spectrum of the soil column is computed between the top and the bottom of this soil deposit. The change in the intensity and the frequency content of the motion due to the propagation of seismic waves in soil deposits and the existence of topographic features, commonly referred to as site effects, have a direct impact on the response of 
structures during each of these earthquake events [1]. Geotechnical earthquake engineering deals with the effects of earthquakes on people and environments. Thus, engineering geologist and geotechnical earthquake engineers try to find most appropriate methods to reduce the magnitude of earthquake related hazards.

Evaluation of ground response is one of the most crucial problems encountered in geotechnical earthquake analysis. Ground response analyses are used to predict surface ground motions for development of design response spectra, to evaluate dynamic stresses and strains for evaluation of liquefaction hazards, and to determine the earthquake-induced forces that can lead to instability of earth and earth-retaining structures [2].

In this regard first quantitative studies have been conducted using strong-motion data after 1970s. Several methods have been proposed for evaluating site effects by using ground motion data, such as soil-torock spectral ratios [3], a generalized inversion [4, 5], and horizontal-to-vertical spectral ratios $[6,7,8,9,10$, $11,12,13]$.

The acceleration response spectra are mainly used to predict the effects of earthquake magnitudes on the relative frequency content of ground-bedrock motions. Even though seismic waves generally travel tens of kilometers of rock and less than $100 \mathrm{~m}$ of soil, the soil plays a very important role in determining the characteristics of ground motion [2]. Due to the complexity of the nonlinearity mechanism, dynamic behavior of soil during strong ground shaking has not been evaluated quantitatively based on the observed ground-motion records. Among the various aspects of the local site effects, nonlinear soil response in sedimentary layers during strong ground shaking has been a controversial issue for a long time [14]. A number of experimental works have been done to establish the stress - strain behavior of various types of soil $[15,16]$

In theory, the term of site amplification refers to the increase in the amplitudes of seismic waves as they pass through the soft soil layers near the earth's surface. The increase is due to the low impedance of soil layers near the surface, where impedance is defined as the product of the mass density of soil and the wave propagation velocity. One of the basic problems to be solved by geotechnical engineers in regions, where earthquake hazards exist, is to estimate the site-specific dynamic response of the soil deposit under a level ground motion. The solution of this problem allows the geotechnical engineers to evaluate the potential for liquefaction, to conduct the first analytical phase of seismic stability evaluations for slopes and embankments, to calculate site natural periods, to assess ground motion amplification, and to provide structural engineers with various parameters, primarily response spectra, for design and safety evaluations of structures [17].

The acceleration time histories thus obtained together with the complete description of the dynamic properties of the soils determined from geophysical seismic studies are used to understand the responses of the soil columns to earthquake waves. Understanding of site response of geological materials under seismic loading is an important element in developing a wellestablished constitutive model.

Analytical methods for site response analysis include many parameters. The effects of these parameters are important to investigate on site response analysis in order to make confident evaluations of earthquake ground motions at the site. $[13,15,18]$ investigated the effects of site parameters such as secant shear modulus, low-strain damping ratio, types of sand and clay, location of water table, and depth of bedrock. These studies have shown that the secant shear modulus, depth of bedrock, and types of sand and clay have a significant effect on the results of site response analysis. However, the low-strain damping ratio and variations of water tables have only a minor influence on site response analysis [19]. There are two approaches methods in site response analysis. These approaches have commonly been employed for representing soil stress-strain behavior during cyclic loading, for application in site response analysis. The first, in which the soil is modeled by a series of springs and frictional elements (Iwan model), uses Masing's rules to establish the shape of the cyclic, hysteresis curves [20].

This model does not normally simulate cyclic loading of soils, observed strain dependence of the shear modulus and damping ratio. On the other hand, Masing's rule does not provide an adequate approximation simultaneously for shear modulus and damping ratio. In the second approach, damping is modeled as a viscous. This approach is adopted, which uses a pseudo-linear treatment, and applies an iterative procedure in order to account for the strain dependence of modulus and damping [21].

The linear model is one of the most widely used approaches to model soil nonlinearity. To approximate the actual nonlinear, inelastic response of soil, an equivalent linear approach was proposed by [21]. In the equivalent linear approach, linear analyses are performed with soil properties that are iteratively adjusted to be consistent with an effective level of shear strain induced in the soil. [22, 23, 24] showed that equivalent linear analysis shows larger peak 
acceleration because the method calculates acceleration in high frequency range large.

The main shortcoming of the linear method is its inability to take account of the strong strain dependence observed experimentally for shear modulus and damping ratio. The best that can be done with the linear model is to apply the method of iterations, and to set values of shear. Site response analysis can be of two kinds. These methods are linear and nonlinear site response analysis. Here are two basic approaches is made. Previous earthquakes, the ground motions on soft soil sites were found to be generally larger than those of nearby rock outcrops, depending on local soil conditions. Therefore, the linear response assay was developed. In order to conduct one-dimensional site response analyses, EERA [10] and NERA [11] softwares are used. The dynamic site response analyses led to results including spectral amplifications, velocities and accelerations. These methods are a modern implementation of the well-known concepts of site response analysis. [25] studied the effect of nonlinearity on site response analysis and evaluated ground surface response, taking into account the local soil and subsurface soil properties for the proposed bridge over the river at Sirdjan Boulevard road subjected to earthquake vibration with the assumption of rigid viscoelasticity. They showed that based on onedimensional site response analysis, the effect of nonlinear soil behavior is one of the key factors for response spectra. They showed that based on onedimensional site response analysis, the effect of nonlinear soil behavior is one of the key factors for response spectra. In another study, the ground response functions at the free surface in different geological locations in the metropolitan area of İstanbul have been obtained using average wave velocities, thicknesses, and densities of the geological layers based on the PS logs from seven different boring logs with depth ranging from 43 to $60 \mathrm{~m}$ during the MARMARAY Project. The E-W component of the acceleration record of the August 17, 1999 Kocaeli earthquake at Beşiktas, district on the rock has been transferred to NERA software to obtain response and design spectrums that are considered to be crucial during earthquake strong ground motion [26].

A similar study, [27] studied in LNG port project in Assaluyeh, situated south of Iran. In their paper, the one-dimensional ground response of a near-fault earthquake is compared by two methods. An equivalent linear method based on total stress modeling in frequency domain and a nonlinear method based on effective stress modeling in time domain.

The main objective of this paper is to compare the linear (EERA) and nonlinear (NERA) site response analysis techniques with the numerically approach and to show their similarities and differences.

\section{Linear and nonlinear site response analyses methods}

To seismic soil response, two approaches are considered: the equivalent linear approach and a nonlinear elastoplastic modeling. In the following, theory and background of these two methods are reviewed.

\section{The equivalent linear site response analysis (EERA)}

The nonlinearity of soil behavior is known very well thus most reasonable approaches to provide reasonable estimates of site response is very challenging area in geoscience. The theory of approximation of real nonlinear dynamic soil behavior by equivalent linear approach was proposed firstly by [21]. Equivalentlinear modeling of dynamic soil behavior utilizes relationships that describe the variation of shear strain of material shear modulus (G) and hysteretic damping

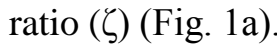

Previous earthquakes, the ground motions on soft soil sites were found to be generally larger than those of nearby rock outcrops, depending on local soil conditions. In order to conduct one-dimensional site response analyses, EERA software is used [10]. The dynamic site response analyses led to results including spectral amplifications, velocities and accelerations. Twelve different material properties are used in analyses conducted via EERA software. EERA is a modern implementation of the well-known concepts of equivalent linear earthquake site response analysis.

$$
\rho \frac{\partial^{2} u}{\partial t^{2}}=\frac{\partial \tau_{h v}}{\partial v}+\frac{\partial \sigma_{h}}{\partial h}+\frac{\partial \tau_{h n}}{\partial n}
$$

Where $\rho$ is unit soil mass density, $u$ is horizontal displacement, $t$ is time, $\tau_{h v}$ is shear stress in the vertical plane within which horizontal displacement occurs, $\sigma_{h}$ is axial stress (positive when tensile) in direction of displacement $u, \tau_{h v}$ is shear stress in the plane perpendicular to the plane within which horizontal displacement occurs, $v, h, n$ are the vertical, horizontal and normal direction respectively (Eq.1).

If one-dimensional wave propagation is considered instead of three-dimensional propagation then the stress gradients $\partial \sigma_{h} / \partial h$ and $\partial \tau_{h n} / \partial n$ are zero and only the stress gradient $\partial \tau_{h v} / \partial v$ exists. Using zero stress gradients $\partial \sigma_{h} / \partial h$ and $\partial \tau_{h n} / \partial n$ in one-dimensional analysis causes inevitably under prediction of the horizontal acceleration $\partial^{2} u / \partial t^{2}$ near basin edges. An apparent increase in $\partial \tau_{h v} / \partial v$ is necessary in onedimensional analysis to compensate for the ignored stress gradients $\partial \sigma_{h} / \partial h$ and $\partial \tau_{h n} / \partial n$ near basin edges. 
Equation (1) is valid for any stress-strain relationship but cannot be solved directly because it mixes stresses with displacements [2]. In real materials, part of the elastic energy of a traveling wave is always converted to heat. Viscous damping is often used to represent this dissipation of elastic energy because of its mathematical convenience. For the purpose of visco elastic wave propagation analysis, soil is usually represented as Kelvin-Voigt model [2].

One way to address the issues of basin edge effects in to define and use modification factors for onedimensional analyses near basin edges. The factors would be used in conjunction with one-dimensional analyses, to determine site specific seismic hazards caused by local ground layers.

The equation of motion in the horizontal direction for a three-dimensional elastic soil is developed in many textbooks [2].

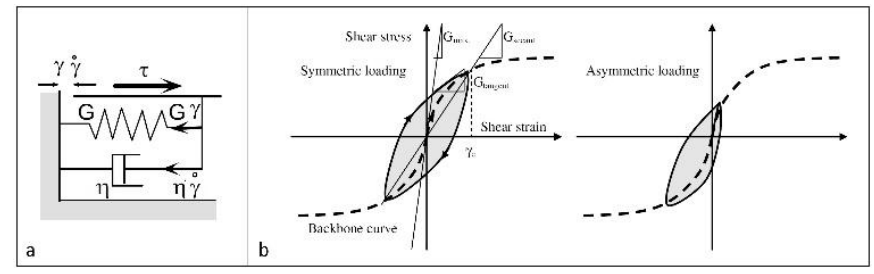

Figure 1. One-dimensional layered soil deposit system [21].

$$
\tau_{h v}=G \cdot \gamma_{h v}+\eta \cdot \frac{\partial \gamma_{h v}}{\partial t}
$$

Where $G$ is shear modulus, shear strain $\gamma_{h v}=\partial u / \partial v$ and $\eta$ is the viscosity of soil $G=\xi(\pi f)^{-1}, \xi$ is damping ratio, $f$ is the frequency of shear stress reversal and $t$ is time. The equation for one-dimensional wave propagation becomes [21] (Eq.2).

In this part, equivalent linear approximation of nonlinear stress - strain response in EERA is described

$$
\rho \cdot \frac{\partial^{2} u}{\partial t^{2}}=G \cdot \frac{\partial^{2} u}{\partial v^{2}}+\eta \cdot \frac{\partial^{3} u}{\partial v^{2} \partial t}
$$

The analysis is usually performed in frequency domain because of its high speed in comparison with time domain analysis (Eq.3). Ground motion is represented by a Fourier series for a number of frequencies $f$. Soil viscosity $\eta$ is related to the damping ratio $\xi$ as $\eta=G$. $\xi(\pi \cdot f)^{-1}$. Because of the modulus and damping ratio non-linear dependence on shear strain magnitude, an equivalent linear approach is used in the computation in frequency domain [21].

An increase in $\partial^{2} u / \partial t^{2}$ in equivalent one-dimensional analyses is considered by factoring actual transversal wave velocities of soil layers in one-dimensional analyses.
These relationships are commonly referred to as modulus reduction and damping curves. One of the first computer programs developed for this purpose was SHAKE [21]. SHAKE computes the response in a horizontally layered soil-rock system subjected to transient and vertical traveling shear waves. SHAKE assumes that the cyclic soil behavior can be simulated using an equivalent linear model, which is extensively described in the geotechnical earthquake engineering literatures [2].

The width of the hysteretic loop is related to the area, which is a measure of internal energy dissipation. The dissipation involves the transformation of energy or work into heat, by particles friction due to their movements. A damping ratio $\xi$ is frequently used as a measure of the energy dissipation [2].

$$
\xi=\frac{W_{D}}{4 \cdot \pi \cdot W_{S}}=\frac{1}{2 \cdot \pi} \cdot \frac{A_{\text {loop }}}{G_{\text {secant }} \cdot \gamma_{c}^{2}}
$$

Where $W_{D}$ is the dissipated energy, $W_{S}$ is the maximum strain energy, i.e. the area of the triangle in Fig. 1b. bordered by $G_{\text {secant }}$ line, the vertical at $\gamma_{c}$ and shear strain axis; and $A_{\text {loop }}$ is the area of the hysteretic loop (Eq.4). Soil parameters $G_{\text {secant }}$ and $\xi$ are often referred to as equivalent linear soil parameters.

In the equivalent linear approach, as previously described in Fig. 1b, the shear modulus and damping ration are taken as functions of shear strain amplitude by iterations so that they become consistent with the level of the strain induced in each layer. The effective shear strain of the equivalent linear analysis is calculated as:

$$
\gamma_{s f f}=R_{y} \gamma_{\max }
$$

$\left(\gamma_{\max }\right.$ is the maximum shear strain in the layer and $R_{y}$ is a strain reduction factor).

\section{Nonlinear and Hysteretic Model (NERA)}

As illustrated in Fig. 2a, [28] and [29] proposed to model nonlinear stress-strain curves using a series of $n$ mechanical elements, having different stiffness $k_{i}$ and sliding resistance $R_{i}$. Her after, their model is referred to as the IM model. The sliders have increasing resistance (i.e., $\mathrm{R}_{1}<\mathrm{R}_{2}<\ldots<\mathrm{R}_{\mathrm{n}}$ ). Initially the residual stresses in all sliders are equal to zero. During a monotonic loading, slider $i$ yields when the shear stress $\tau$ reaches $R_{i}$. After having yielded, slider $i$ retains a positive residual stress equal to $R_{i}$. As shown in Fig. $2 \mathrm{~b}$, the stress-strain curve generated by the IM model for two sliders (i.e, $n=2$ ) is piecewise linear, whereas the corresponding slope and tangential modulus $H$ varies in steps. In the case of an IM model with $n$ sliders, the stress increment $d \tau$ and strain increment $d \gamma$ are related through: 


$$
d \tau / d \gamma=H
$$

Where the tangential modulus $H$ is:

$$
H=\left\{\begin{array}{lr}
H_{1}=k_{1} & \text { if } 0 \leq \tau<R_{1} \\
H_{2}=\left(k_{1}^{-1}+k_{2}^{-1}\right)^{-1} & \text { if } R_{1} \leq \tau<R_{2} \\
H_{n-1}=\left(k_{1}^{-1}+k_{2}^{-1}+\cdots+k_{n-1}^{-1}\right)^{-1} & \text { if } R_{n-2} \leq \tau<R_{n-1} \\
H_{n}=\left(k_{1}^{-1}+k_{2}^{-1}+\cdots+k_{n-1}^{-1}+k_{n}^{-1}\right)^{-1} & \text { if } R_{n-1} \leq \tau<R_{n}
\end{array}\right.
$$

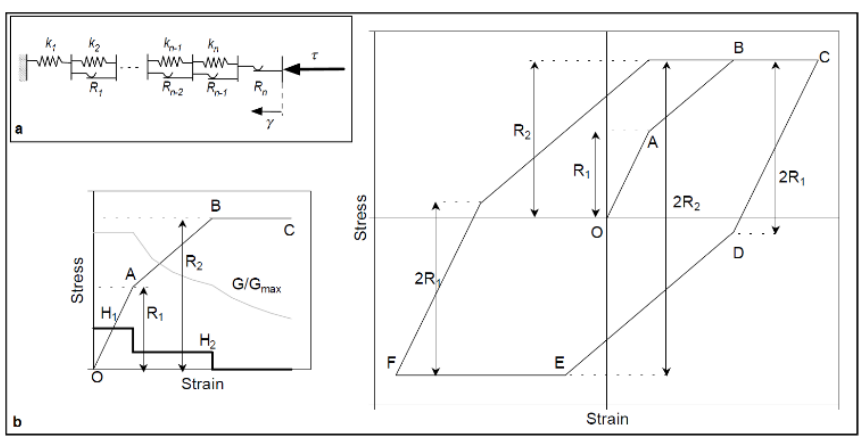

Figure 2. Backbone curve (left) during loading and hysteretic stress-strain loop (right) of IM model during loading-unloading cycle [11].

As shown in Fig. $2 b$, the stress-strain curve during a loading is referred to a backbone curve. When the loading changes direction (i.e., unloading), the residual stress in slider $i$ decreases; slider $i$ yields in unloading when its residual stress reaches $-R_{i}$, i.e., after the stress $\tau$ decreases $-2 R_{i}$. Instead of yield stress, it is convenient to introduce the back stress $\alpha_{\mathrm{I}}$ : slider $i$ yields in loading and unloading when $\tau$ becomes equal to $\alpha_{\mathrm{I}}+R_{i}$ and $\alpha_{\mathrm{I}}$ $R_{i}$, respectively. The IM model assumes that parameters $R_{i}$ are constant whereas the back stress $\alpha_{\mathrm{I}}$ varies during loading processes. As shown in Fig. 2b, the cyclic stress-strain curves are hysteretic, and follows Masing similitude rule [30]. Curve CDEF is obtained from curve $\mathrm{OABC}$ by a simitude with a factor of 2 .

The stress-strain curves of the IM model can be calculated using the algorithm. This algorithm returns an exact value of stress $\tau$ independently of the strain increment amplitude $\Delta \gamma$. At first, the algorithm attempts to calculate the stress increment $\Delta \tau$ using the strain increment $\Delta \gamma$ and modulus $H_{l}$. If $\tau+\Delta \tau \leq \alpha_{1}+R_{1}$ (loading), then $\tau+\Delta \tau$ is accepted; the stress is smaller than the yield stress of slider 1 . If $\tau+\Delta \tau>\alpha_{1}+R_{1}$, the strain increment $\Delta \gamma$ was too large, and the stress $\tau+\Delta \tau$ exceeded the yield stress of slider 1 ; the tangential modulus of the stress-strain response was $H_{1}$ only for the stress increment $\Delta \tau=\alpha_{1}+R_{\mathrm{i}}-\tau$ and strain increment $\Delta \tau / H_{1}$. The algorithm is reapplied to slider 2, instead of slider 1 , using the remaining strain increment $\Delta \gamma$ $\Delta \tau / H_{1}$. The algorithm is repeated for other sliders until $\tau+\Delta \tau$ becomes smaller than the yield stress of slider $j$. Each time, the remaining strain increment referred to as $\Delta x$ becomes smaller. At this time, the back stresses of sliders 1 to $j-1$ are updated. The algorithm works for loading and unloading through the use of variable $\mathrm{x}$, which is set to 1 for loading and -1 for unloading respectively.

The nonlinear backbone curve of Fig. $2 b$ can be described in terms a variation of secant shear modulus $G$ with shear strain $\gamma$, especially by $n$ data points, i.e., $G_{i}-\gamma_{\mathrm{I}}, \mathrm{i}=1, \ldots, \mathrm{n}$. In this case, the tangential shear modulus $H_{i}$, is related to the secant modulus $G_{i}$, as follows:

$$
H_{i}=\frac{G_{i+1} \gamma_{i+1}-G_{i} \gamma_{i}}{\gamma_{i+1}-\gamma_{i}} \quad i=2, \ldots \ldots, n-1 \text { and } H_{n}=0
$$

Assuming that the back stress $\alpha_{i}$ is initially equal to zero, $R_{i}$ is:

$$
R_{i}=G_{i} \gamma_{i} \quad i=1, \ldots, n
$$

Equations 8 and 9 imply that the maximum shear resistance is $R_{n}=G_{n} \gamma_{n}$ i.e., is specified by the last point of the $G-\gamma$ curve. When the $G / G_{\max }-\gamma$ are specified, then Eqs. 8 and 9 become:

$$
\begin{gathered}
H_{i}=G_{\max } \frac{G_{i+1} \gamma_{i+1}-G_{i} \gamma_{i}}{\gamma_{i+1}-\gamma_{i}} \quad i=2, \ldots \ldots, n-1 \\
\text { and } R_{i}=G_{\max } G_{i}^{\prime} \gamma_{i} \quad i=1, \ldots, n
\end{gathered}
$$

Where

$$
G_{i}^{\prime}=G_{i} / G_{\max }
$$

\section{Geological and Tectonic Setting}

The geology of the area consists of Paleozoic and Cenozoic-age formations (Fig. 3). The Trakya formation of the Paleozoic-age is represented by sandstone, siltstone, and claystone alternations and forms the basement in the study area. Unconformable overlying Miocene age deposits are differentiated as the Çukurçeşme, Güngören, and Bakırköy formations and constitute clastics, fine-grained and precipitated sediments, respectively, denoting a fluvial-to-lacustrine depositional environment. Alluvial deposits are limited to roughly north-south trending creek or stream valleys. Based on drill holes by the MARMARAY Tube Tunnel Project-2005 in the vicinity of the excavation site, a simplified geological section is produced (Fig. 4). Artificial filling and part of the Quaternary deposits are located above the present sea level. At the boundary of the Quaternary and Miocene deposits, a dark gray-black clay deposit is found in a small depression-like paleotopographical setting.

We considered it a small swamp, formed on the floodplain of Lykos Stream along an abandoned distributary channel, as indicated by tree roots and abundant plant material.

Based on surface geology investigations and evaluation of the findings of 107 borings carried out in the area and its vicinity for various purposes, the local 
geological sequence and soil profile are established. These studies indicate that Neogene deposits outcrop in the region which comprises a sequence of strata unconformable overlying the Lower Carboniferous greywacke (Trakya fm.) and Eocene limestones (Kurklareli fm.). The Neogene sequence, deposition of which started transgressively in Late Oligocene, is composed of from bottom to top, basal gravel and conglomerate, interbedded green over consolidated clay and sand, and in the upper zone, due to a lacustrine environment getting shallower at the end of the Miocene, gray-green sand, organic clay, white/cream marl and fossiliferous limestone interbedded with clay (Bakırköy fm.) as an uninterrupted sequence. Fig. 3 shows the location of the site in the geological map of İstanbul [32], [33], and Fig. 4 displays the geographical positions of the borings and the grid overlay used in the area. The geological map of the study area is given in Fig. 3.
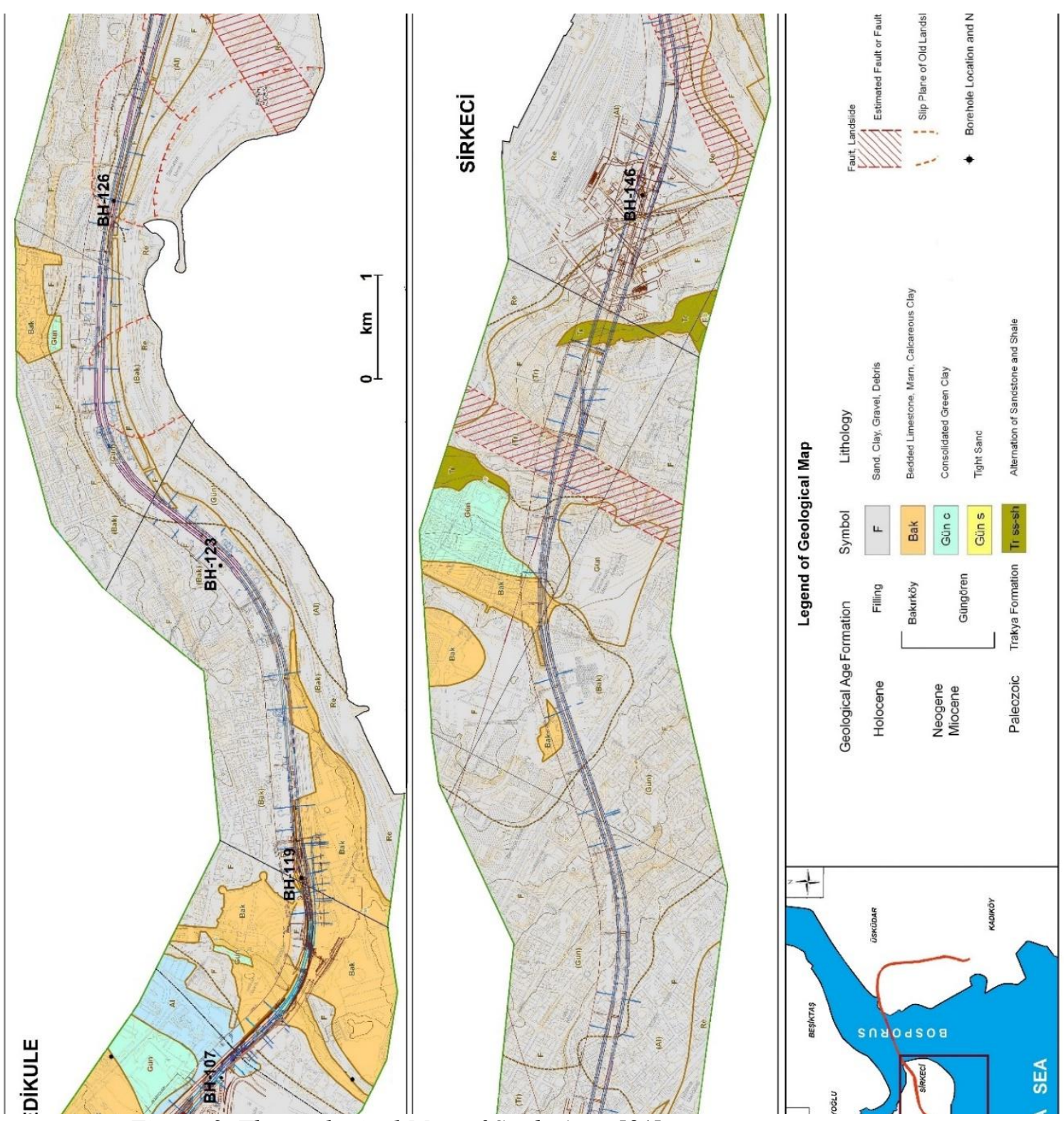

Figure 3. The geological Map of Study Area [31]. 


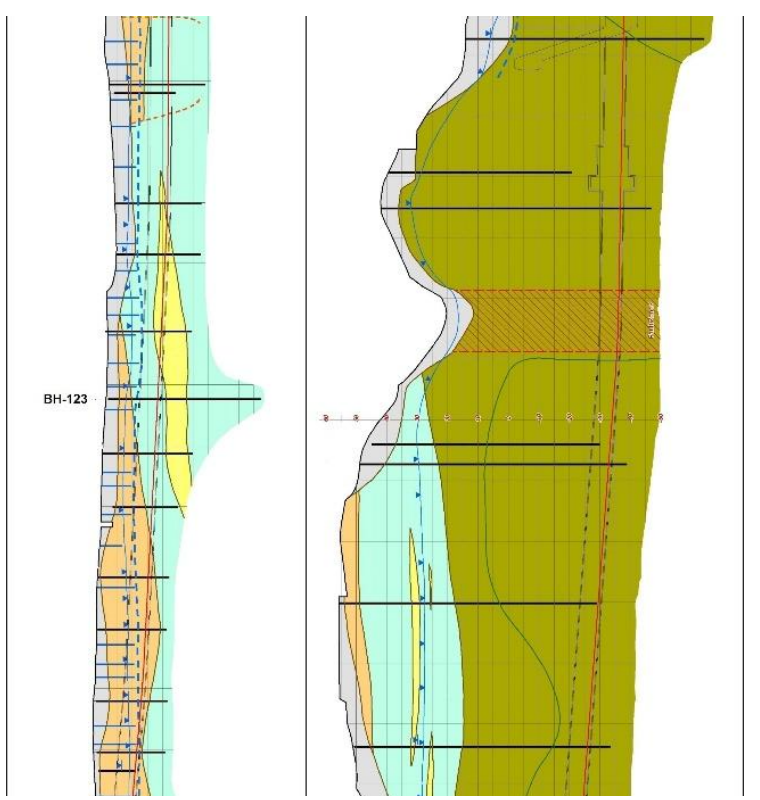

Figure 4. MARMARAY structure cross section and boreholes locations [31].

The site has widespread outcrops of limestone/marl inter bedded and transitional with limy clay, belonging to the Bakırköy formation, which is $20-30$ m thick. The lithologies forming the Bakırköy formation are not only marls and low-strength limestone. It is, in fact, a sequence of inter bedded sand, clay, marl and limestone. The underlying Gürpınar formation is composed of green, fissured, over consolidated clays occasionally inter bedded with sand layers, only outcrops in a small area near the northeast end of the site, as a result of faulting. While the Gürpınar formation is $40-60 \mathrm{~m}$ thick towards the north end of the site, data from water wells up to $250 \mathrm{~m}$ deep confirm that the formation gets thicker towards the south and southwest and reaches to a thickness of 200 $\mathrm{m}$ in the coastal zone. The formation is unconformable on the Trakya formation in the north and, as shown in cross-section A-A' (Fig. 4), unconformable on the Middle Eocene-Lower Oligocene Kurklareli formation in the southern half of Zeytinburnu province [34].

The second stage excavations of İstanbul Metro are carried out generally in Trakya and Güngören formation. Trakya formation (TF) consists of sandstone-siltstone-claystone-shale sequences. Limestone and conglomerates layers are also rarely observed. There are diabase and andesite dykes having some $10 \mathrm{~m}$ thickness. In the south of tunnel alignment, middle-upper age Miocene sediments consists of Çukurçeşme formation containing loose gravel-sandsilt, Güngören formation with clay-marn layer and Bakırkoy formation having limestone with shale and marl [35]. Many faults and geologic discontinuities exist in the area due to Alpine Orogenies. The overburden thickness above the tunnels varies between
11 and $42 \mathrm{~m}$, and the distance between going-coming tunnels varies between 30 and $32 \mathrm{~m}$.

The Marmara region is tectonically very active. The North Anatolian Transform Fault Zone (NAFZ) cuts across the region in an E-W direction, following the major axis of the Sea of Marmara. In the region the rate of right-lateral offset along the NAFZ has been measured to be about $18 \mathrm{~mm} / \mathrm{yr}$ [36], [37]. The NAFZ is widely known to have generated large earthquakes $(\mathrm{M}>7)$ at $125-150 \mathrm{yr}$ intervals. In the Düzce and Kocaeli (İzmit) earthquakes of 1999, the lateral offset along the fault locally exceeded $5 \mathrm{~m}$ [38], [39]. The İstanbul area is a fault block bounded on the south by the NAFZ and on the north by the South Boundary Fault of the Black Sea Basin [40], [41]. This faultbounded block is forced to rotate anticlockwise due to the sinistral shear. This rotation is expressed clearly in the geomorphology; major hills and the valleys trend obliquely to the two faults, following a long way before reaching the surrounding seas. Simultaneously with the anticlockwise rotation, the fault block has been elevated at a rather slow rate of about $0.2 \mathrm{~mm} / \mathrm{yr}$. However, these tectonically induced slow vertical motions have not caused radical changes in the study area during the recent $8000-10,000 \mathrm{yr}$ period. But, some more remarkable local vertical movements caused by the activities of the NAFZ cannot be ruled out.

\section{Geotechnical Properties of the Study Area}

The dynamic properties of the soils in the area were evaluated by use of the data obtained from seven boreholes. The soil classes in the upper $30 \mathrm{~m}$ are dominantly silty sand and clays of high/low plasticity. These evaluations underline poor engineering conditions of soils beyond Southern Coasts of İstanbul. 
A basic statistical evaluation of the soil property database will be utilized to better characterize the soils in the area. From the Fig. 4 it can be reliably expounded that the dominant characteristic of the soils are silty/clayey sand, sandy/gravel, gravel and clays of high/low plasticity.

MARMARAY line, from BH-119 borehole to until BH-130A boreholes are located in Güngören formation also to The Marmara Sea from BH-130A borehole is located in the Thrace formation. On the fault zone in the Thrace formation is clearly observed the intensity of tectonic deformation in the region. Accordingly, $\mathrm{BH}-$ 107, BH-119 and BH-123 boreholes are comprised from sand, clay and gravel mixtures. BH-126, BH-130A, BH-134 and BH-146 boreholes after deep the $30 \mathrm{~m}$ are composed of mudstone, claystone and sandstone.

\section{The Linear and Nonlinear Site Response Analyses of the Study Area}

İstanbul is the largest city in Turkey and the area has experienced high levels of earthquake ground motion. Four earthquakes of M 7.6 (1509, 1719, and 1766) and M 7.0 (1894) situated in the Marmara Sea have generated intensities up to $\mathrm{X}-\mathrm{XI}$ in the city Following the 1999 Kocaeli earthquake, the high probability of a large event affecting İstanbul in the near future has been put forward by various researchers [42], [43]. There are two main hypotheses about the rupture characteristics of this event. [44] argue that a large magnitude earthquake ( $\mathrm{Mw}$ 7.6-7.7) caused by a 175 $\mathrm{km}$ through going rupture of the so-called Main Marmara Fault (northern strand of the North Anatolian Fault in the Marmara Sea) will take place in the near future. On the other hand, based on their observations on submarine fault scarps in the Marmara Sea, [45] argue that the 1912 Ganos earthquake on the westernmost on-land segment of the Main Marmara Fault crossed the Ganos restraining bend into the Sea of Marmara for $60 \mathrm{~km}$ with a right-lateral slip of $5 \mathrm{~m}$, ending in the Central Basin step-over. These findings result in a total rupture length of $140 \mathrm{~km}$ for the 1912 event, contradicting the $50 \mathrm{~km}$ on-land rupture, previously suggested by [46].

[47] made a comprehensive deterministic approach to the earthquake hazard in İstanbul city. Therefore, the scenario earthquakes were computed by deterministic seismic hazard analysis integrated with time-dependent probabilistic hazard assessments by [48] and [49].

Obtain the site response results, analyses are conducted by use of EERA and NERA softwares in this study. The EERA and NERA softwares are in spreadsheets format and has the ability to include unlimited dynamic soil models in soil response calculations by one dimensional linear and nonlinear methods. A damped linear elastic model and nonlinear analyses are used to demonstrate the nonlinear behavior of the soil layers. The stress-strain properties of the soils are instructed by use of the relationships expressing the change of shear modulus and damping with the shear strain level. Thus, the soil profiles were prepared from the database for the calculation of average shear wave velocities.

\section{Selection of Ground Motion Records}

The studied sites are subjected to ground motion caused by events originated in the plate inshore seismic zones. One acceleration record from in plate zones were selected for the site response analysis of the soil deposit. The earthquake Kocaeli 1999, with PGA (magnitude $=7.4 \mathrm{Mb}$ ) value of $0,04287 \mathrm{~g}$, at Prime Ministry Disaster \& Emergency Management Presidency İstanbul Station (PMDEMPIS) for site, the Fourier spectra is shown in Fig. 5.

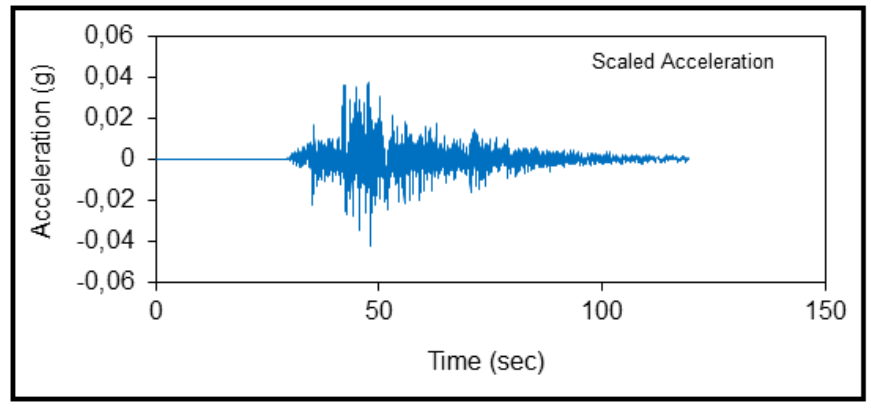

Figure 5. Record of accelerograph of horizontal component of The earthquake Kocaeli 1999 at IBMPWS station obtained from PMDEMPIS online virtual data center.

Local soil is mainly sandy clay and clays of high/low plasticity poorly graded but usually very dense. It can be seen that these time histories present relatively high frequencies, high accelerations and long durations as it is common in this region.

Input time history are applied on each of the soil profiles by the EERA and NERA softwares to obtain the site responses, and the resulting database consisted of dynamic soil behavior, including spectral acceleration-time variation as well as its maximum.

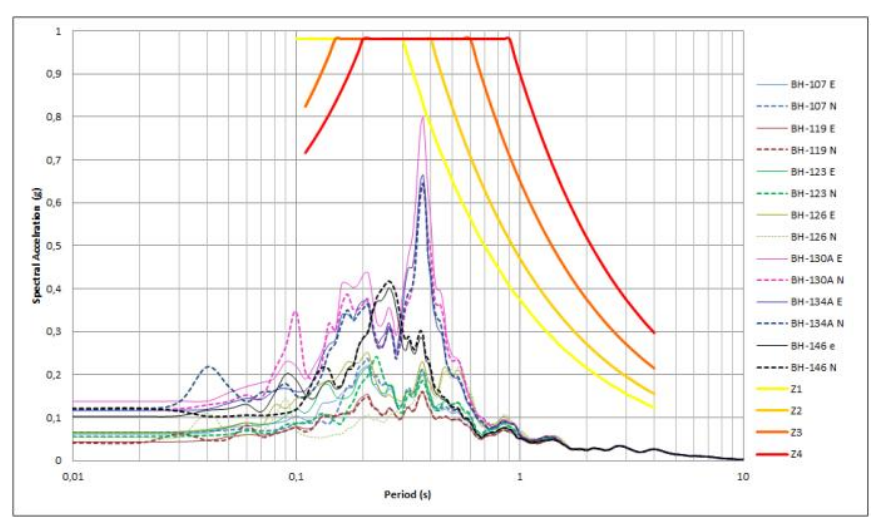


Figure 6. Exemplary surface spectral accelerationperiod relationships belonging to various boreholes of the investigation area and comparison of the earthquake Kocaeli 1999 elastic behavior acceleration spectrums with Turkish Earthquake Regulation Spectrums (2007 elastic medium, EERA and NERA).

Seven exemplary surface spectral acceleration-period variations from different boreholes are given in Fig. 6 . Borings in separate grids were evaluated under the given input time history and the maximum spectral acceleration against period variation is determined in each boring location. During past earthquakes, the ground motions on soft soil sites were found to be generally larger than those of nearby rock outcrops, depending on local soil conditions.

[50] made a comprehensive deterministic approach to the earthquake hazard in İstanbul city. By İstanbul Metropolitan Municipality (IMM) for İstanbul city earthquake scenario was constructed by the method of Kobayashi-Midorikawa. The study included a comparison of fifteen different earthquake scenarios. Comparison of these scenarios led to the conclusion that an earthquake which is probable to occur on NAFZ will generate ground motions having a magnitude of approximate $\mathrm{Mw}=7.5$, radiating an energy level greater than those of the rest of the scenarios [51]. In order to obtain the site response results, analyses are conducted by use of EERA [10] and NERA [11] softwares.

\section{Modeling of Profile Geometry and Soil Properties}

Generalized soil profiles were established from the borehole drilled at $\mathrm{BH}-107, \mathrm{BH}-119, \mathrm{BH}-123 \mathrm{BH}-126$, BH-130A, BH-134 and BH-146 boreholes. The wells are located along the MARMARAY line. All boreholes are located in alluvial soil. Because of the lower shearwave zone and the lower shear strengths values were measured in boreholes. Modulus of rigidity or shear modulus can be explained using elastic properties of soil layers. Shear modulus of soils for the site analysis is determined by [16].

EERA and NERA programs obtained change of max shear stress with depth are shown in Fig. 7. Accordingly, the max shear stress-depth change in $\mathrm{BH}$ 126, BH-130A, BH-134 and BH-146 boreholes are seen in the range of $25 \mathrm{kPA}-50 \mathrm{kPA}$ in EERA method. If the method of NERA, the max shear stress-depth change in $\mathrm{BH}-123, \mathrm{BH}-126, \mathrm{BH}-130 \mathrm{~A}, \mathrm{BH}-134$ and $\mathrm{BH}-146$ boreholes are seen in the range of $20 \mathrm{kPA}-40 \mathrm{kPA}$. Moreover, BH-107, BH-119 and BH-123 boreholes are in low acceleration category in EERA. If the method of NERA, BH-107 and BH-119 boreholes are in low acceleration category. According to Fig.8, change max shear stress-depth of these boreholes are monitored in the range of $16 \mathrm{kPA}-20 \mathrm{kPA}$ in EERA method, $10 \mathrm{kPA}$ $15 \mathrm{kPA}$ in NERA method.

Focusing on Fig. 8, it can be stressed that the alluvial region near The Marmara Sea, soils especially under Kazliçeşme, Yenikapı and Zeytinburnu district the lowest shear wave velocities, ranging between $0-100$ $\mathrm{m} / \mathrm{s}$. The shear wave velocity $\left(\mathrm{V}_{\mathrm{S} 30}\right)$ variation of the soils given in Fig. 8 enlightens the reason of the low strength of the soils in the area, which is dominancy of these soil classes. Shear wave velocities of upper $65 \mathrm{~m}$ are between 194-518 m/s at BH-107, BH-119 and BH123 boreholes. Shear wave velocities for layers deeper than 20 meters are between $782-2173 \mathrm{~m} / \mathrm{s}$ at $\mathrm{BH}-126$, BH-130A, BH-134 and BH-146 boreholes. Furthermore, outcropping bedrock in the BH-134 and BH-146 boreholes are probably the reason of the V values between greater than $950 \mathrm{~m} / \mathrm{s}$. MARMARAY route constitutes the basis of the Thrace formation. Some boreholes into this formation extend.

The shear modulus increases drastically from $140 \mathrm{MPa}$ to $240 \mathrm{MPa}$ at depth of 35 meters and decreases drastically from $240 \mathrm{MPa}$ to $140 \mathrm{MPa}$ at depth of $20 \mathrm{~m}$ at $\mathrm{BH}-130 \mathrm{~A}$ borehole, and shear modulus decreases from $200 \mathrm{MPa}$ to $160 \mathrm{MPa}$ at depth of 17 meters at $\mathrm{BH}$ 107 borehole. Furthermore, the shear modulus increases dramatically from $480 \mathrm{MPa}$ to $1300 \mathrm{MPa}$ at depth of 54 meters at BH-126 borehole. Accordingly, the shear modulus increases dramatically from $50 \mathrm{MPa}$ to 6500 $\mathrm{MPa}$ at depth of 34 meters at BH-134 borehole and from $400 \mathrm{MPa}$ to $1800 \mathrm{MPa}$ at depth of 22 meters at BH-146 borehole (Fig. 8).

According to the results of the EERA method solution; The amplitude ratios (1.3-8 ratio) values of acceleration are seen to be different in boreholes. The amplitude ratios of the $\mathrm{BH}-107, \mathrm{BH}-119$ and $\mathrm{BH}-123$ are low. However, other boreholes, the amplitude ratios are high (3-8 ratio) (Fig.9). Frequency of maximum amplification $(\mathrm{Hz})$ and maximum amplification values are given in Table-1. Frequency of maximum amplification $(\mathrm{Hz})$ in $\mathrm{BH}-123$ borehole is high $(7.4 \mathrm{~Hz})$, BH-126 borehole is low $(2.0 \mathrm{~Hz})$. Similarly, maximum amplification in $\mathrm{BH}-130 \mathrm{~A}$ borehole is high (7.83), $\mathrm{BH}-$ 119 borehole is low (1.23).

According to the results of the NERA method solution; The amplitude ratios (1.4-8.5 ratio) values of acceleration are seen to be different in boreholes. The amplitude ratios of the $\mathrm{BH}-107, \mathrm{BH}-119, \mathrm{BH}-130 \mathrm{~A}$ and BH-134 are low. However, other boreholes, the amplitude ratios are high (5.5-8 ratio) (Fig. 9). Frequency of maximum amplification $(\mathrm{Hz})$ and maximum amplification values are given in Table-1. Frequency of maximum amplification $(\mathrm{Hz})$ in $\mathrm{BH}-126$ borehole is high $(49.7 \mathrm{~Hz}), \mathrm{BH}-126$ borehole is low 
$(8.05 \mathrm{~Hz})$. Similarly, maximum amplification in $\mathrm{BH}-$ 123 borehole is high (36.27), BH-119 borehole is low (2.0).

The Fourier response in the form of spectra indicates the ideal situation of variation in amplitudes at different frequencies. BH-146 borehole away from these two wells is over and marine sediments.

Therefore, the spectral acceleration values are high. In addition, Fig. 10 demonstrates the variation of peak spectral acceleration values in the investigation area. Calculated surface spectral accelerations in the area ascend to $0.80 \mathrm{~g}$, and the observed lowest value is 0.15 g. with EERA method. If the method of NERA, calculated surface spectral accelerations in the area ascend to $0.65 \mathrm{~g}$, and the observed lowest value is 0.16 g. Because, these wells are located in the area of marine sediments. Analyzing the Table-1, it is seen that majority of $\mathrm{BH}-130 \mathrm{~A}$ and $\mathrm{BH}-134$ boreholes are in high acceleration category.

According to the EERA and NERA methods, they are understood that majority of $\mathrm{BH}-130 \mathrm{~A}, \mathrm{BH}-134$ and $\mathrm{BH}-146$ boreholes are under high ground shaking risk (Table 2). Additionally, individual areas in the shoreline to Marmara Sea and creek beds are under the threat of relatively medium to low ground shaking risk. Small areas of relatively low ground shaking risk are observed in BH-107, BH-119, BH-123 and BH-126 boreholes.

\section{Conclusions}

MARMARAY is a very large project for İstanbul. A million people carrying capacity per day is a railway project. The construction of such a major project, could be planned the largest earthquake in the region. The study area due to NAFZ has a very high seismic risk. To obtain response spectra for design of structures the spectral acceleration values for layers deposited at the sites were defined using computer programs EERA and NERA. MARMARAY project is many boreholes drilled. However, the seven boreholes were examined in this study.

Hence, PS logging and $\mathrm{V}_{\mathrm{S}}$ measured in seven boreholes were transferred to EERA and NERA softwares. Then, calculated by the EERA and NERA softwares soil

\begin{tabular}{|c|c|c|c|c|c|c|c|c|c|c|c|c|c|c|}
\hline \multirow[t]{2}{*}{ Boreholes } & \multicolumn{2}{|c|}{ BH-107 } & \multicolumn{2}{|c|}{ BH-119 } & \multicolumn{2}{|c|}{ BH-123 } & \multicolumn{2}{|c|}{ BH-126 } & \multicolumn{2}{|c|}{ BH-130A } & \multicolumn{2}{|c|}{ BH-134 } & \multicolumn{2}{|c|}{ BH-146 } \\
\hline & EERA & NERA & EERA & NERA & EERA & NERA & EERA & NERA & EERA & NERA & EERA & NERA & EERA & NERA \\
\hline $\begin{array}{l}\text { Maximum } \\
\text { Amp. }\end{array}$ & 1.58 & 2.88 & 1.23 & 2.00 & 1.73 & 36.27 & 2.87 & 11.01 & 7.83 & 2.96 & 6.05 & 2.58 & 5.16 & 5.26 \\
\hline $\begin{array}{l}\text { Freq. of } \\
\text { Max. Amp. } \\
(\mathrm{Hz})\end{array}$ & 2.8 & 8.05 & 2.4 & 18.92 & 7.4 & 48.68 & 2.0 & 49.70 & 2.6 & 28.62 & 2.8 & 17.15 & 3.8 & 12.33 \\
\hline
\end{tabular}

Table 1. Maximum amplification and frequency of maximum amplification $(\mathrm{Hz})$ of boreholes 


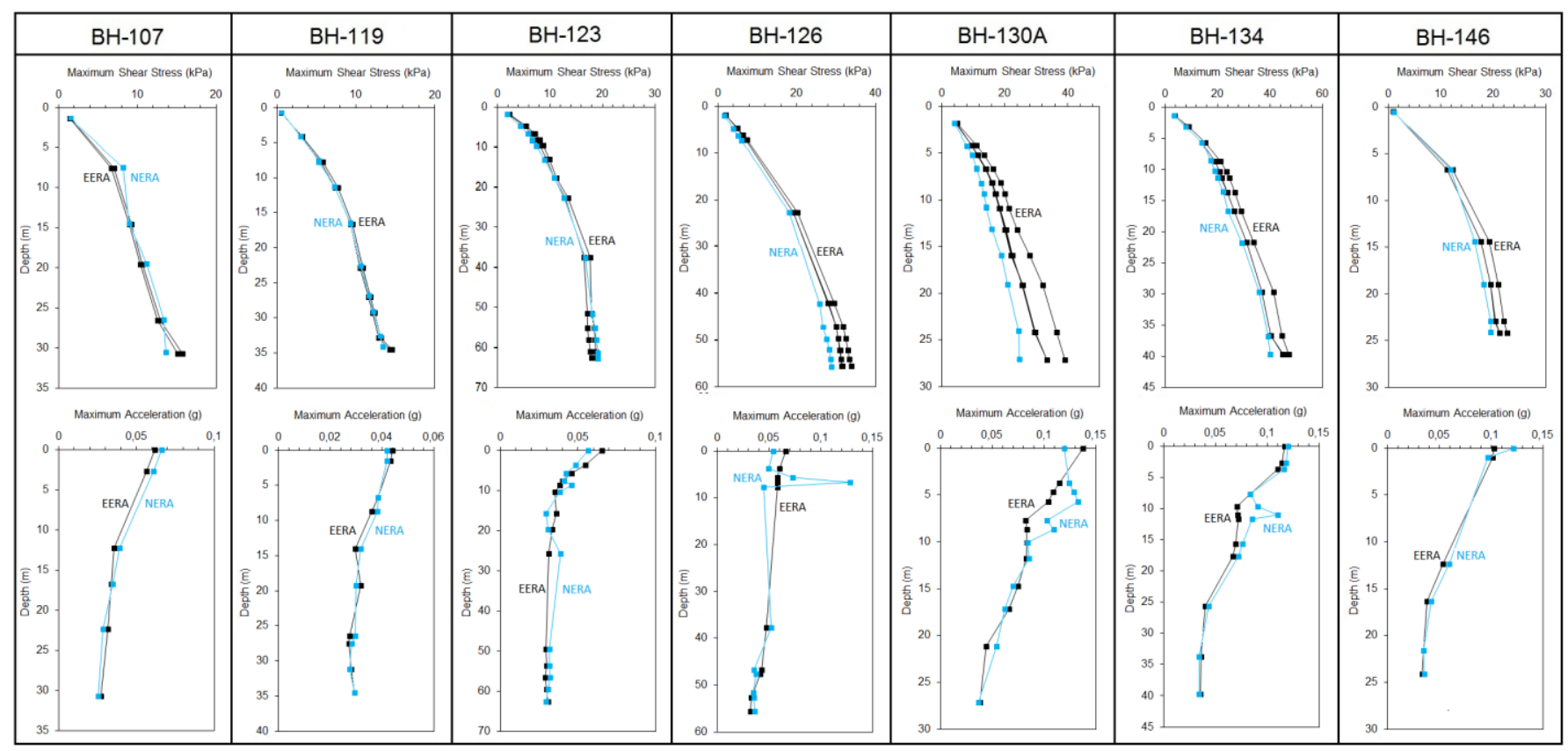

Figure 7. Max shear stress variation with depth of the boreholes (Results of the $1 D$ ground response analysis performed with EERA and NERA)

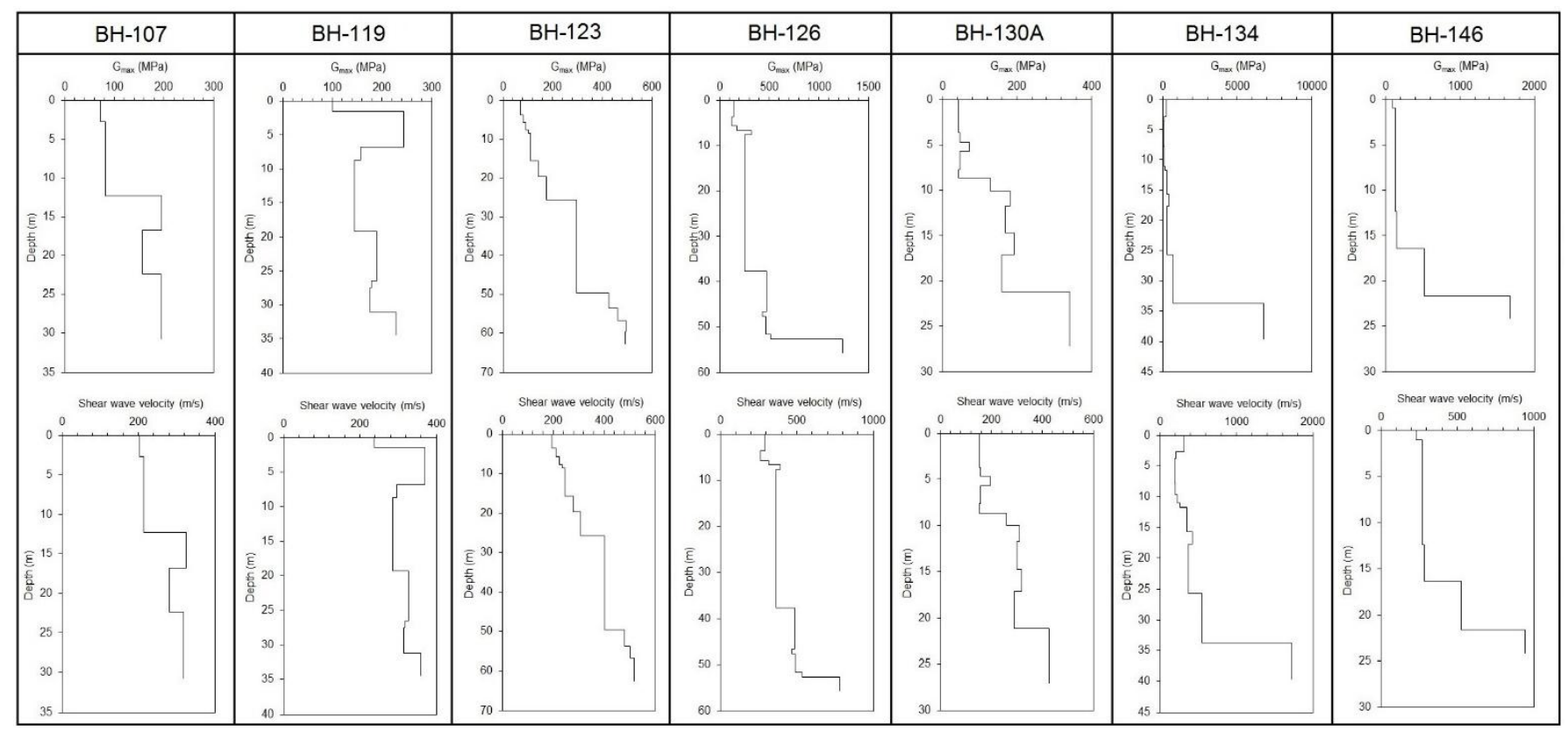

Figure 8. $G_{\max }$ - depth and shear stress - depth variation graphics of the boreholes (from EERA and NERA)

Table 2. Max Period $(s)$ and max spectral acceleration $(g)$ of boreholes

\begin{tabular}{|c|c|c|c|c|c|c|c|c|c|c|c|c|c|c|}
\hline \multirow[t]{2}{*}{ Boreholes } & \multicolumn{2}{|c|}{ BH-107 } & \multicolumn{2}{|c|}{ BH-119 } & \multicolumn{2}{|c|}{ BH-123 } & \multicolumn{2}{|c|}{ BH-126 } & \multicolumn{2}{|c|}{ BH-130A } & \multicolumn{2}{|c|}{ BH-134 } & \multicolumn{2}{|c|}{ BH-146 } \\
\hline & EERA & NERA & EERA & NERA & EERA & NERA & EERA & NERA & EERA & NERA & EERA & NERA & EERA & NERA \\
\hline Max Period (s) & 0.21 & 0.21 & 0.36 & 0.37 & 0.21 & 0.23 & 0.21 & 0.53 & 0.37 & 0.37 & 0.37 & 0.37 & 0.23 & 0.25 \\
\hline $\begin{array}{l}\text { Max Spectral } \\
\text { acceleration } \\
\text { (g) }\end{array}$ & 0.22 & 0.24 & 0.15 & 0.16 & 0.21 & 0.24 & 0.25 & 0.22 & 0.80 & 0.65 & 0.66 & 0.64 & 0.44 & 0.45 \\
\hline
\end{tabular}




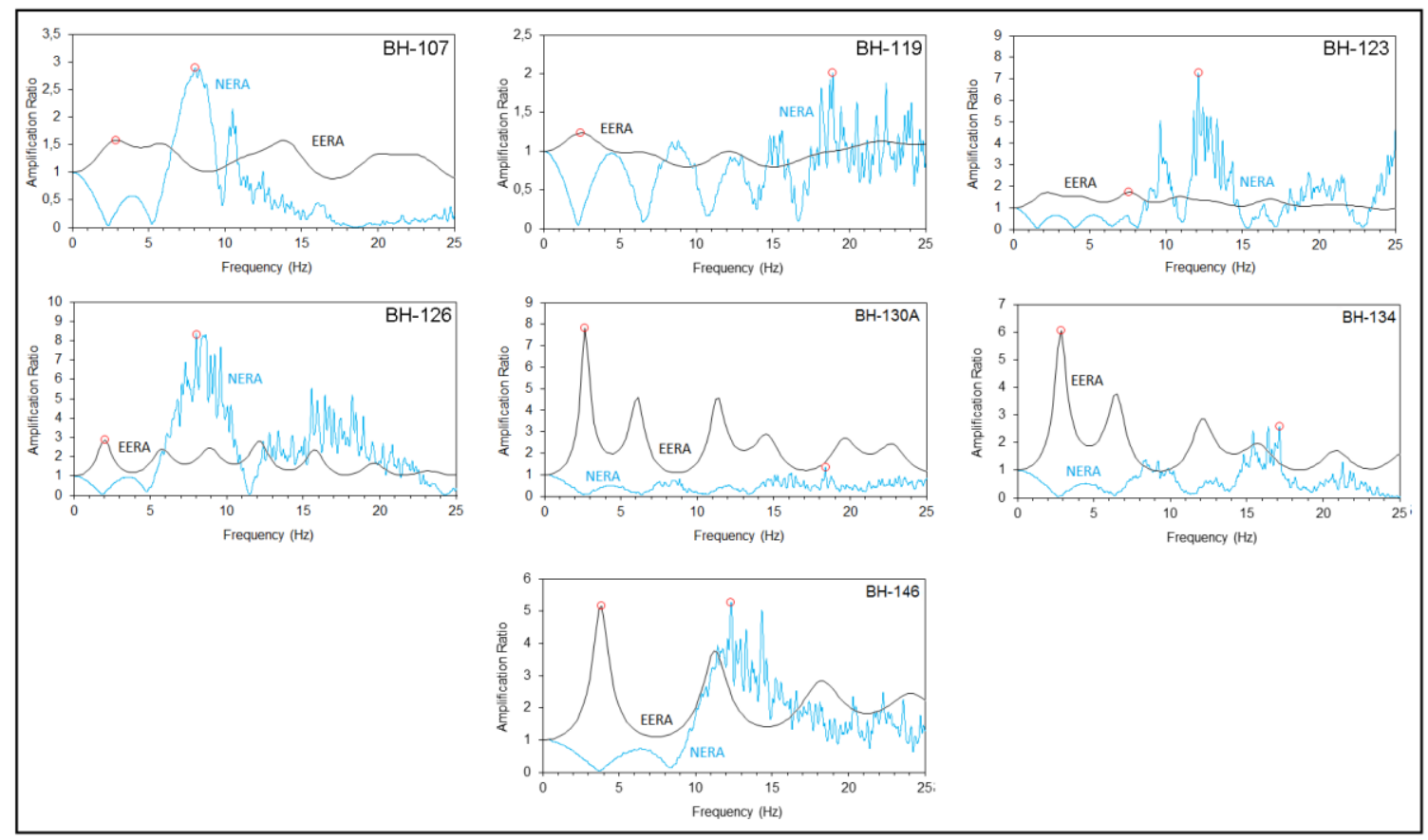

Figure 9. Amplitude ratio values of acceleration in boreholes (comparative EERA and NERA).

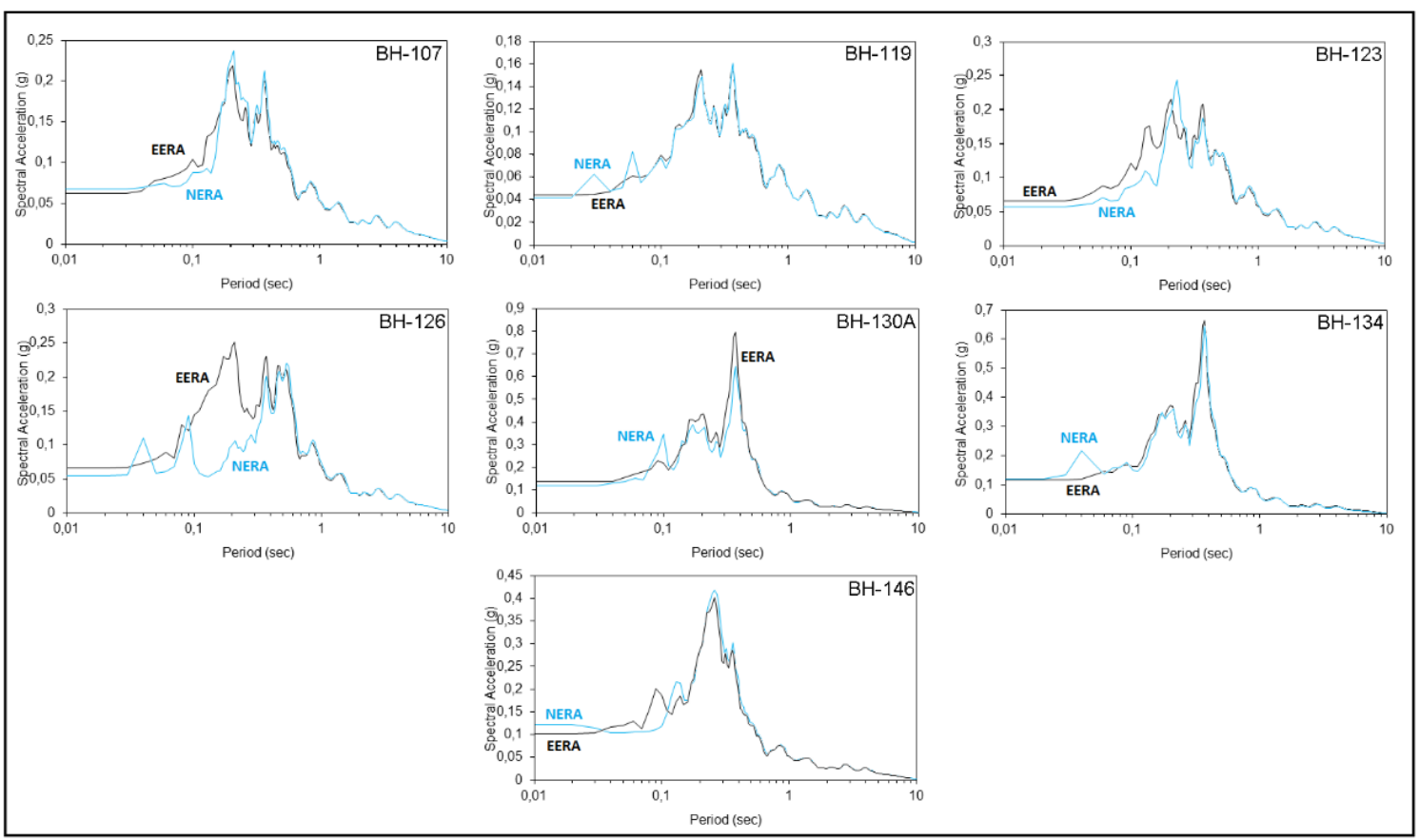

Figure 10. Spectral acceleration and Period relationship of the boreholes (comparative EERA and NERA)

Table 3. The calculated maximum values of boreholes.

\begin{tabular}{|c|c|c|c|c|c|}
\hline \multicolumn{3}{|c|}{ Time Domain } & \multicolumn{2}{c|}{ Frequency Domain } \\
\hline $\begin{array}{l}\text { Borehole } \\
\text { Number }\end{array}$ & $\begin{array}{c}\text { Acceleration } \\
(\mathrm{g})\end{array}$ & $\begin{array}{c}\text { Particular } \\
\text { Velocity } \\
(\mathrm{m} / \mathrm{s})\end{array}$ & $\begin{array}{c}\text { Displacement } \\
(\mathrm{m})\end{array}$ & $\begin{array}{c}\text { Spectral } \\
\text { Acceleration } \\
(\mathrm{g})\end{array}$ & $\begin{array}{c}\text { Dominant Period } \\
(\mathrm{s})\end{array}$ \\
\hline \multicolumn{7}{|c|}{ 17 Aug Kocaeli earthquake acceleration record of $0.04287 \mathrm{~g}$ was measured at the IBMPWS } \\
\hline BH-107 & 0.062 & 0.002 & 0.031 & 0.22 & 0.21 \\
\hline
\end{tabular}




\begin{tabular}{|c|c|c|c|c|c|}
\hline BH-119 & 0.044 & 0.001 & 0.026 & 0.15 & $\mathbf{0 . 3 6}$ \\
\hline BH-123 & 0.065 & 0.003 & 0.037 & 0.22 & 0.21 \\
\hline BH-126 & 0.066 & 0.003 & 0.043 & 0.25 & 0.21 \\
\hline BH-130A & $\mathbf{0 . 1 3 8}$ & 0.004 & 0.073 & 0.80 & $\mathbf{0 . 3 7}$ \\
\hline BH-134 & $\mathbf{0 . 1 1 7}$ & 0.003 & 0.064 & 0.66 & $\mathbf{0 . 3 7}$ \\
\hline BH-146 & $\mathbf{0 . 1 0 3}$ & 0.001 & 0.038 & 0.40 & 0.26 \\
\hline
\end{tabular}

parameters and behavior acceleration spectrums are compared with Turkish Earthquake Regulation.

The results obtained from the geological and engineering investigations have provided useful information regarding the physical and engineering properties of the surface soil samples as well as alluvium and land-slide materials at dam site and reservoir area. EERA and NERA calculations have produced plenty of data describing the response of the boreholes under 17 August Kocaeli earthquake, where the results can be processed in several boreholes. Therefore, the joints between stations are important but weaker parts of the earthquake-resistant design of the MARMARAY tunnel. Not only must they have superior anti-deformation properties, but they are also observed to prevent unacceptable deformation under seismic loading. Hence, more attention should be paid to seismic response analysis of the flexible joints.

According to spectral acceleration-period graphics, there is a difference $300 \mathrm{~m} / \mathrm{s}$ velocity between down layer and top layer in BH-130A borehole in EERA methods. Similarly, there is a difference $700 \mathrm{~m} / \mathrm{s}$ velocity between down layer and top layer in $\mathrm{BH}-134$ borehole, there is a difference $1900 \mathrm{~m} / \mathrm{s}$ velocity between down layer and top layer $\mathrm{BH}-146$ borehole. Spectrums of BH-126, BH-130A, BH-134 and BH-146 boreholes show similar features (Fig. 10).

With regard to NERA method there is a difference $\sim 100 \mathrm{~m} / \mathrm{s}$ velocity between down layer and top layer in BH-107 borehole. Similarly, there is a difference $\sim 1400 \mathrm{~m} / \mathrm{s}$ velocity between down layer and top layer in BH-134 borehole. Also, spectrums of BH-119, BH130A and $\mathrm{BH}-134$ boreholes show similar features; on the other hand $\mathrm{BH}-107, \mathrm{BH}-126$ and $\mathrm{BH}-146$ boreholes show similar features (Fig. 10).

At the location of stations connections where there are joint points, Fig. 8 illustrates the lower shear strengths values of tunnel build when the seismic waves are propagating along all over directions, lower shear-wave zone when the seismic waves are propagating along all over directions. Due to the alteration of the soil, surface layer thickness is $3-5 \mathrm{~m}$. The impact of the building on the soil has been ratio of $5 \%$.

According to EERA method, dominant period from $0.36 \mathrm{~s}$ to $0.37 \mathrm{~s}$ are increasing in $\mathrm{BH}-119, \mathrm{BH}-130 \mathrm{~A}$ and $\mathrm{BH}-134$ boreholes. If the method of NERA, dominant period from $0.37 \mathrm{~s}$ to $0.53 \mathrm{~s}$ are increasing in BH-119, BH-126, BH-130A and BH-134 boreholes. Therefore, this area is expected to become more dominant low frequency $\mathrm{S}$ waves. The largest maximum accelerations were measured in the $\mathrm{BH}$ 130A borehole to EERA method, in the BH-119 borehole to NERA method. Similary the lowest maximum acceleration was measured in the BH-119 borehole to EERA method, in the BH-119 borehole to NERA method.

Accelerations of the $\mathrm{BH}-130 \mathrm{~A}, \mathrm{BH}-134$ and $\mathrm{BH}-146$ boreholes at the time domain same results were scaled in both EERA and NERA methods. In both methods, maximum accelerations are input acceleration $(0,0426$ g) increase (1-2 storey). In acceleration the largest amplification $(0.138 \mathrm{~g})$ is in BH-130A borehole to EERA method (Table 3). Similary in acceleration the largest amplification $(0.120 \mathrm{~g})$ are in BH-130A, BH134 and BH-146 boreholes to NERA method (Table 3).

On the other hand amplification ratio-frequency graphics for each borehole in Figure 9 reflect approximate vibration frequency values of the soil layers from the free surface to the deep end of the borehole, as apparent from the comparison of Figures 4 and 9. Maximum amplification ratios for $\mathrm{BH}-126$ and BH-123 boreholes increase to 8 as compared to BH-119 and BH-130A boreholes having value of 2 in NERA method, because the former boreholes were drilled within the consolidated green clay layers. Similarly, maximum amplification ratios for $\mathrm{BH}-130 \mathrm{~A}$ and $\mathrm{BH}-$ 134 boreholes increase (within the fault zone) to 6-8 as compared to $\mathrm{BH}-107, \mathrm{BH} 119$ and $\mathrm{BH}-123$ boreholes having value of 2 in EERA method, because the former boreholes were drilled within the consolidated green clay and tight sand layers.

Therefore, this area is of low frequency $\mathrm{S}$ wave. The largest maximum acceleration was measured in the $\mathrm{BH}$ - 
130A (in EERA) borehole. Large spectral amplitudes shift larger periods because EERA and NERA analysis has been carried out using a relatively far seismic source, namely the 17 August 1999 İzmit earthquake $(\mathrm{Mw}=7.4)$. The effective peak acceleration is $0.3 \mathrm{~g}$; the fundamental period is about $0.15-0.53 \mathrm{~s}$ for the long distance scenario earthquakes. These period intervals are characteristic for the $\mathrm{Z} 3$ type of soil $\left(\mathrm{T}_{\mathrm{A}}=0.15 \mathrm{~s}\right.$ and $\mathrm{T}_{\mathrm{B}}=0.60 \mathrm{~s}$ ) given in the Earthquake Design Code of Turkey [51]. The width of the spectrum is dominated by the local soil type and the effective ground acceleration determines the peak value of the spectral acceleration between the short and long characteristic periods. Based on these plots a slightly modified design spectrum of $\mathrm{Z} 3$ type of soils is proposed as shown in Fig. 6 with colored lines.

The lowest maximum acceleration was measured in the BH-119 borehole. For an input acceleration value of $0.0426 \mathrm{~g}$, maximum accelerations of the $\mathrm{BH}-130 \mathrm{~A}$, BH-134 and $\mathrm{BH}-146$ boreholes in the time domain are obtained to be between 0.42-0.65, indicating amplifications in the order of ten folds. These boreholes are considered to be located within the fault zone (Table 3).

Since fundamental periods of boreholes labelled as $\mathrm{BH}$ $119, \mathrm{BH}-130 \mathrm{~A}$ and $\mathrm{BH}-134$ are $0.37 \mathrm{~s}$, sites of these boreholes are in $\mathrm{Z3}$ soil class. On the other hand $\mathrm{BH}-$ $130 \mathrm{~A}$ and $\mathrm{BH}-134$ boreholes are within the fault zone and their accelerations values are obtained to be high such as 0.64-065 g. Within the boreholes under investigation, the maximum fundamental period value $(0.53 \mathrm{~s})$ is estimated for $\mathrm{BH}-126$ and the site of this borehole, therefore, is deemed suitable as $\mathrm{Z} 4$ soil class. The periods of the other boreholes (e.g. BH-107, BH123 and $\mathrm{BH}-146)$ are in the range $0.21-0.25 \mathrm{~s}$ and their sites are classified as Z2 soil class.

\section{Acknowledgements}

The authors would like to thanks MSc. Sercan ÖZTÜRK and TAISEI Corporation.

\section{References}

[1] Y. M. A. Hashash, D. R. Grohalski, C. A. Philips, "Recent advances in nonlinear site response analysis", 5th International Conference on Recent Advances in Geotechnical Earthquake Engineering and Soil Dynamics No.4. Sandiego California, 2010.

[2] S. L. Kramer, "Geotechnical Earthquake Engineering", 1st edn. Prentice-Hall, New Jersey, 1996.

[3] R. D. Borcherdt, "Effects of local geology on ground notion near San Francisco Bay", Bull. Seismol. Soc. Am. 60: 29-81, 1970.
[4] T. Iwata, K. Irikura, "Source parameters of the 1983 Japan Sea earthquake sequence", J. Phys. Earth. 36:155-184, 1988

[5] J. Boatwright, J. B. Fletcher and T. E. Fumal, "A general inversion scheme for source, site and propagation characteristics using multiply recorded sets of moderate-sized earthquakes", Bull. Seism. Soc. Am., 81, 1754-1782, 1991.

[6] Y. Nakamura, "On the urgent earthquake detection and alarm system (UrEDAS)", In: Proceedings of World. Conference in Earthquake Engineering, 1988.

[7] J. Lermo, F. J. Chavez-Garcia, "Site effects evaluation using spectral ratios with only one station", Bull Seismol. Soc. Am. 83: 1574-1594, 1993.

[8] E. H. Field, K. H. Jacob, "A comparison and test of various site-response estimation techniques, including three that are not reference-site dependent", Bull. Seism. Soc. Am. 85: 11271143,1995.

[9] F. Yamazaki, M. A. Ansary, "Horizontal-tovertical spectrum ratio of earthquake ground motion for site characterization", Earthquake Eng. Struct. Dyn. 26: 671-689, 1997. JSSMFE: 14-31

[10] J. P. Bardet, K. Ichii, C. H. Lin, "EERA, A Computer Program for Equivalent Linear Earthquake Site Response Analysis of Layered Soils Deposits", University of Southern California, Los Angeles, 2000.

[11] J. P. Bardet, T. Tobita, "NERA: A computer program for nonlinear earthquake site response analyses of layered soil deposits", Department of Civil Engineering, University of Southern California, Los Angeles, CA, 43 pp, 2001.

[12] I. Lam, C. F. Tsai, G. R. Martin, "Determination of site dependent spectra using nonlinear analysis", In: 2nd international conference on microzonation, San Francisco, CA, 1978.

[13] W. B. Joyner, A. T. F. Chen, "Calculation of nonlinear ground response in earthquakes", Bull. Seismol. Soc. Am. 65: 1315-1336, 1975.

[14] S. M. M. M. Hosseini and M. A. Pajouh, "Comparative study on the equivalent linear and the fully nonlinear site response analysis approaches", Arab. J. Geosci. 5:587-597, 2012. DOI 10.1007/s12517-010-0228-9

[15] H. B. Seed, I. M. Idriss, "Soil moduli and damping factors for dynamic response analysis", Report EERC 70-10, 1970. University of California, Berkeley, Earthquake Engineering Research Center. 
[16] B. O. Hardin, V. P. Dmevich, "Shear modulus and damping in soil: measurement and parameter effects" J. Soil Mech. Found Div. 98: 603-624, 1972.

[17] E. Şafak "Local site effects and dynamic soil behavior", Soil Dynamics and Earthquake Engineering 21, 453-458, 2001.

[18] H. H. M. Hwang, C. S. Lee, "Parametric study of site response analysis", Soil Dyn. Earthq. Eng. 10 (6): 282-290, 1991.

[19] H. Arslan and B. Siyahi, "A comparative study on linear and nonlinear site response analysis", Environ Geol. 50: 1193-1200, 2006. DOI 10.1007/s00254-006-0291-4

[20] H. B. Seed, R. V. Whitman, H. Dezfulian, R. Dobry, I. M. Idriss, "Soil conditions and building damage in the 1967 Caracas earthquake", J. Soil Mech Found Div. ASCE 98:787-806, 1972.

[21] P. B. Schnabel, J. Lysmer, H. B. Seed, "SHAKE: a computer program for earthquake response analysis of horizontally layered sites", 1972. Report No. EERC72-12, University of California, Berkeley.

[22] N. Yoshida, "Applicability of conventional computer code SHAKE to nonlinear problem", Proc. Symposium on Amplification of Ground Shaking in Soft Ground, JSSMFE, pp14-31, 1994. (in Japanese)

[23] H. C. Huang, C S. Shieh, H. C. Chiu, "Linear and nonlinear behaviors of soft soil layers using Lotung downhole array in Taiwan" Terr. Atmos. Ocean Sci. 12: 503-524, 2001.

[24] N. Yoshida, S. Iai, "Nonlinear site response analysis and its evaluation and prediction", In: 2nd International symposium on the effect of surface geology on seismic motion, Yokosuka, Japan, pp 71-90, 1998.

[25] A. A. Shahri, B. Esfandiyari, H. Hamzeloo, "Evaluation of a nonlinear seismic geotechnical site response analysis method subjected to earthquake vibrations (case study: Kerman Province, Iran)". Arab J Geosci 4:1103-1116, 2011.

[26] G. Beyhan, A. Keskinsezer and S. Öztürk, "Soil properties and applications review with NERA (nonlinear earthquake site response analyses) in İstanbul-MARMARAY Project between Kazlıçeşme to Sirkeci”, Environmental Earth Science January, 75:93, 2016. DOI 10.1007/s12665-015-4783-y

[27] M. Adampira, H. Alielahi, M. Panji and H. Koohsari, "Comparison of equivalent linear and nonlinearmethods in seismic analysis of liquefiable site response due to near-fault incident waves: a case study", Arab J Geosci 8:3103-3118, 2015.

[28] W. D. Iwan, "On a class of models for the yielding behavior of continuous and composite systems, Journal of Applied Mechanics", ASME, Vol. 34, pp.612-617, 1967.

[29] Z. Mróz, "On the description of anisotropic workhardening", Journal of Mechanics and Physics of Solids, Vol.15, pp.163-175, 1967.

[30] G. Masing "Eigenspannungen und Verfestigung beim Messing", Proceedings of the Second International Congress of Applied Mechanics, pp.332-335, 1926.

[31] TAISEI, Marmaray project map, 2011 (unpublished).

[32] M. Yıldırım, "Engineering Geological evaluation of solid waste landfill sites: two examples from İstanbul, Turkey", Bulletin of Engineering Geology 55, 151-158, 1997.

[33] M. Yıldırım, E. Savaşkan, "İstanbul Tersiyer Çökellerinin Stratigrafisi ve Mühendislik Özellikleri”, Uluslararası Mühendislik Jeolojisi Türk Milli Komitesi Bülteni, 18, pp. 48-62, 2002. İstanbul (in Turkish)

[34] K. Özaydın, A. Ansal, M. Erdik, M. Yıldırım, H. Kılıç, Ş. Adatepe, P. T. Özener, M. Tonoroğlu, K. Şeşetyan, M. Demircioğlu, "Earthquake Master Plan For İstanbul, Zeytinburnu Pilot Project", "Report on Geological and Geotechnical Evaluation for Seismic Microzonation and Seismic Microzonation for Ground Shaking" Yıldız Tecknical University, Fac. of Civil Eng. Geotechnical Department., Boğaziçi University, Kandilli Observatory and Earthquake Research Inst. (in Turkish), 2004.

[35] E. Usta, "İstanbul Metro Yenikapi-Unkapani engineering geology", Master Thesis, İstanbul Technical University, İstanbul, Turkey, 2004.

[36] F. Flerit, R. Armijo, G. C. P King, B. Meyer, A. Barka, "Slip partitioning in the Sea of Marmara pull-apart determined from GPS velocity vectors", Geophysical Journal International 154, 1-7, 2003.

[37] N. Pondard, R. Armijo, G. C. P. King, B. Meyer, F. Flerit, "Fault interactions in the Sea of Marmara pull-apart (North Anatolian Fault): earthquake clustering and propagating earthquake sequences", Geophysical Journal International 171, 1185-1197, 2007.

[38] M. N. Toksöz, R. E. Reilinger, C. G. Doll, A. Barka, N. Yalçın, "Izmit (Turkey) Earthquake of 17 August 1999: first report", Seismological Research Letters 70 (6), 669-679 November/December, 1999. 
[39] R. E. Reilinger, S. Ergintav, R. Bürgmann, S. McClusky, O. Lenk, A. Barka, O. Gürkan, L. Hearn, K. L. Feigl, R. Çakmak, B. Aktuğ, H. Özener, M. N. Töksoz, "Coseismic and Postseismic Fault Slip for the 17 August 1999, $\mathrm{M}=7.5$, Izmit, Turkey Earthquake", Science 289, 1519-1524, 2000.

[40] Y. Y1lmaz, "Morphotectonic development of the southern Black Sea Region and the Bosphorus Channel", In: Yanko-Hombach V, Gilbert A, Panin N, Dolukhanov P (Eds.) The Black Sea Flood Question: Changes in Coastline, Climate, and Human Settlement. NATO Science Series IV-Earth and Environmental Sciences. Kluwer Academic Press, Springer, Dordrecht, The Netherlands, pp. 537-569, 2007.

[41] Y. Yılmaz, G. Gökaşan, A. Y. Erbay, "Morphotectonic development of the Marmara Region", Tectonophysics 488, 51-70, 2010.

[42] X. Le Pichon, A. M. C. Sengor, T. Taymaz, "The Marmara fault and the future İstanbul earthquake", In: Karaca M, Ural DN, editors. ITU-IAHS international conference on the Kocaeli earthquake, 17 August 1999, İstanbul Technical University, Turkey, p. 41-54, 1999.

[43] T. Parsons, "Recalculated probability of M47 earthquakes beneath the Sea of Marmara, Turkey", Journal of Geophysical Research; 109:B05304, 2004. doi:10.1029/2003JB002667

[44] X. Le Pichon, N. Chamot-Rooke, C. Rangin, A. M. C. Şengör, "The North Anatolian Fault in the Sea of Marmara", Journal of Geophysical Research 108 (B4): 2179, 2003. doi:10.1029/ 2002JB001862

[45] R. Armijo, N. Pondard, B. Meyer, G. Uçarkuş, B. M. De Lepinay, J. Malavieille, S. Dominguez, M A. Gustcher, S. Schmidt, C. Beck, N. Çağatay, Z. Cakir, C. Imren, K. Eris, B. Natalin, S. Özalaybey, L. Tolun, I. Lefevre, L. Seeber, L. Gasperini, C. Rangin, Ö. Emre and K. Sarkkavak. "Submarine fault scarps in the Sea of Marmara pull-apart (North Anatolian Fault): Implications for seismic hazard in İstanbul", Geochemistry, Geophysics, and Geosystems: 6 (6) 1-29, 2005. doi:10.1029/2004GC000896

[46] N. N. Ambraseys, C. Finkel, "The SarosMarmara earthquake of 9 August 1912", Journal of Earthquake Engineering and Structural Dynamics, 15/1: 189-212, 1987.

[47] A. Ansal, A. Akinci, G. Cultrera, M. Erdik, V. Pessina, G. Tönük, G. Ameri, "Loss estimation in İstanbul based on deterministic earthquake scenarios of the Marmara Sea region (Turkey)",
Soil Dynamics and Earthquake Engineering 29, 699-709, 2009.

[48] M. Erdik, M. Demircioğlu, K. Sesetyan, E. Durukal, "Assessment of earthquake hazard for Bakirköy, Gemlik, Bandırma, Tekirdağ and Körfez", WB MEER project-A3 component, microzonation and hazard vulnerability studies for disaster mitigation in pilot municipalities, Boğaziçi University, Kandilli Observatory and Earthquake Engineering Research Institute, 2005.

[49] R. Spence, E. So, G. Ameri, A. Akinci, M. Cocco, G. Cultrera, G. Franceschina, F. Pacor, V. Pessina, A. M. Lombardi, G. Zonno, A. Carvalho, A. Campos Costa, E. Coelho, K. Pitilakis, A. Anastasiadis, K. Kakderi, M. Alexoudi, "Technical report on the scenario earthquake definitions for three cities", Deliverable 83, Project lessloss on risk mitigation for earthquakes and landslides, SubProject 10 - earthquake disaster scenario predictions and loss modelling for urban areas. Sixth Framework Programme, 2005.

[50] M. Erdik, Z. Cagnan, C. Zulfikar, K. Sesetyan, M. B. Demircioğlu, E. Durukal, C. Kariptas, "Development of Rapid Earthquake Loss Assessment Methodologies for Euro-MED Region", Proc. 14. World Conference on Earthquake Engrg. Paper ID: S04-004, 2008.

[51] IMM - OYO - Boğaziçi University, Kandilli Observatory and Earthquake Research Institute, 2009, Earthquake scenario of İstanbul city. 